\title{
Literatura:
}

BAUER, J. - MRÁZEK, R. - ŽAŽA, S.: Příruční mluvnice ruštiny pro Čechy. II, Skladba. Praha: Státní pedagogické nakladatelství, 1960.

BERGER, O.: Sintaksičeskije terminy v russkom i češskom jazykach: sopostavitel'nyj aspekt (na materiale vybrannych terminov). Brno: Masarykova univerzita 2021. ISBN 978-80-210-9807-7.

FLÍDROVÁ, H.: Nový pohled na větné členy v ruské a české syntaxi. Opera Slavica, 2021, 2, s. $73-76$.

FLÍDROVÁ, H. - ŽAŽA, S.: Sintaksis russkogo jazyka v sopostavlenii s češskim. Olomouc: Univerzita Palackého, Filozofická fakulta, 2005. ISBN 80-244-1104-o.

SLOVÁK, V.: Synkretizmus větných členů v ruštině a češtině. Sinkretizm členov predloženija v russkom $i$ češskom jazykach. Olomouc: Univerzita Palackého v Olomouci, 2020. ISBN 978-80-244-5617-1.

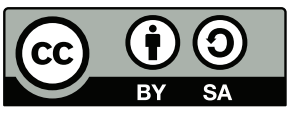

Toto dílo Ize užít v souladu s licenčními podmínkami Creative Commons BY-SA 4.0 International (<https:// creativecommons.org/licenses/by-sa/4.0/legalcode>). Uvedené se nevztahuje na díla či prvky (např. obrazovou či fotografickou dokumentaci), které jsou v díle užity na základě smluvní licence nebo výjimky či omezení príslušných práv.

\section{Nová slovenská publikace o ruském malířství}

FIGEDYOVÁ, M.: Обзор русской живописи от истоков до начала XX века. Brno: Tribun EU, 2019. ISBN 978-80-263-1532-2.

Marianna Figedyová přináší prostřednictvím své publikace Обзор русской живописи от истоков до начала $X X$ века ucelený přehled významných etap ruského výtvarného umění od 9. až do počátku 2o. století. Publikace je koncipována jako výukový text adresovaný především studentům Katedry rusistiky filozofické fakulty Univerzity sv. Cyrila a Metoda v Trnavě, zajisté však bude přínosem také pro širší okruh čtenářů jevících zájem o ruské výtvarné umění. Text seznamuje čtenáře se základními etapami rozvoje ruského výtvarného umění od zrodu ruské ikony až do příchodu ruské avantgardy na počátku 20. století. 
Kompozičně publikace sestává z pěti kapitol, jež reprezentují chronologicky navazující mezníky rozvoje ruského výtvarného umění. Tyto mezníky jsou v úvodu každé kapitoly stručně zasazeny do obecnějšího historického a kulturně-společenského kontextu, díky čemuž čtenář získává možnost pohlédnout na jednotlivé umělce a jejich díla $z$ daleko širší perspektivy a vytvořit si tak lepší povědomí o historické podobě daných epoch.

Svůj výklad autorka zahajuje obdobím 9. a 10. století, během nějž se v rámci sílícího vlivu křestanství na Rusi dostává do centra zájmů tehdejších umělců pravoslavná ikona. Ikoně je v této době přisuzována nejen funkce náboženského symbolu, ale také nástroje šíření křestanské víry. S příchodem ikonopisectví dochází k rozvoji nových uměleckých metod, díky kterým mohou umělci tvořit obrazy ztvárňující samotné „poselství Boží“. Epocha ikonopisectví je v textu reprezentována několika nejznámějšími umělci a jejich obrazy, jejichž fotografie jsou součástí publikace. Zvláštní pozornost je pak věnována symbolice Rublevovy ikony Trojice. Velmi zajímavou součástí kapitoly jsou také informace o významu jednotlivých barev užívaných při malbě ikon.

V následující části se autorka věnuje období klasicismu, kdy se vlivem reforem a politiky Petra I. začaly v umění 18 . století projevovat zahraniční, především pak západní, vlivy a tendence. Ruští umělci získávají jak doma, tak i v zahraničí, možnost studovat nové výtvarné techniky a žánry. Výsadní postavení mezi uměleckými žánry této doby zaujímá portrét. $V$ textu najdeme medailonky několika představitelů dominujících ruských portrétních žánrů 18. století (např. A. M. Matvejeva, F. S. Rokotova aj.). Kromě portrétu se v tomto období prosadil také žánr krajinomalby, reprezentovaný např. díly S. F. Ščedrina nebo F. Ja. Aleksejeva.

Ve svém výkladu se autorka dále chronologicky prresouvá do 19. století. První polovině tohoto století vévodí romantismus a dominantním žánrem je opět portrét. Umělci se snaží co nejlépe vystihnout duševní stav člověka a podtrhnout lidskou individualitu, důraz je kladen na určitou svobodu a originalitu uměleckého projevu. Jako příklad zde autorka uvádí díla O. Kiprenského, A. G. Venecianova, K. P. Brjullova a dalších. Druhé polovině 19. století pak dominuje realismus. Portrét ztrácí pozici výchozího žánru a je nahrazen obrazy se silným sociálním podtextem. V tomto období se objevuje řada novátorských umělců usilujících o to, aby jejich umění napomohlo debatě o změně sociálních poměrů $\mathrm{v}$ zemi. $\mathrm{V}$ textu nalezneme také část věnovanou žánru krajinomalby 19. stol., reprezentovanou např. V. D. Poleonovem, I. K. Ajvazovským atd.

Putování historií ruského umění autorka završuje poslední kapitolou věnovanou epoše modernismu počátku 2o. století. V textu jsou uvedena a charakterizována stěžejní díla daného období (např. Serovova Dívka s broskvemi, Vrubelův Démon aj.). Celý text uzavírají obrazy novátorského umělce K. S. Petrova-Vodkina, jehož díla využívají ikonopiseckých technik, se kterými nás autorka seznámila již v úvodu publikace. 
Celá publikace je koncipována jako obecný přehled jednotlivých etap ruského umění. Každá etapa je reprezentována výčtem osobností, které se zasloužily o její umělecký rozvoj. Je nutno říci, že jednotliví umělci a epochy jsou představeny velmi stručně, avšak jak sama autorka uvádí, učebnice slouží pouze jako odrazový můstek pro potenciální zájemce o (samo)studium ruského umění. Jejím cílem je poskytnout čtenáři pouze základní vhled do dané problematiky. Nehledě na stručnost výkladu se jedná o velmi zajímavý a také čtivý vzdělávací text. Je taktéž chvályhodné, že v závěru každé kapitoly nalezneme doplňující otázky či úlohy k již prostudovanému tématu.

Nehledě na zmíněné klady však nelze opomenout ani určité formální nedostatky, kterých si v textu můžeme povšimnout. Problém spatřuji např́iklad ve způsobu citování některých zdrojů. Dle tvrzení autorky je text zpracován na základě volně dostupných zdrojů, jejichž výčet nalezneme v závěru publikace. $V$ tomto výčtu lze ovšem nalézt i několik webových stránek, jež nepůsobí na první pohled důvěryhodně. Jedná se např. o odkaz na článek webu https://fashioon.ru, u nějž není znám ani autor, ani jiný parametr prokazující hodnověrnost citovaného textu. Mimo to je nutno podotknout, že elektronické zdroje, z nichž bylo pravděpodobně také čerpáno, nejsou uvedeny v souladu s citační normou (pokud z nich bylo přímo či neprrímo citováno, měly by být odkazy opatřeny alespoň základními citačními údaji a neměly by tak zůstávat jen v podobě holého hypertextového odkazu).

Závěrem lze konstatovat, že učebnice PaedDr. Marianny Figedyové, PhD., je zajisté cenným zdrojem informací pro studenty i veřejnost projevující zájem o ruské umění. Při přípravě nového vydání však doporučuji lépe propracovat systém citování elektronických zdrojů a vnést tak do dané problematiky větší transparentnost.

Oksana Dunajeva

\section{Literatura:}

FIGEDYOVÁ, M.: Obzor russkoj živopisi ot istokov do načala XX veka. Brno: Tribun EU, 2019. ISBN 978-80-263-1532-2.

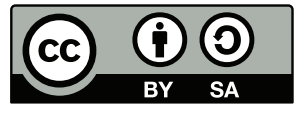

Toto dílo Ize užit v souladu s licenčními podmínkami Creative Commons BY-SA 4.0 International (<https:// creativecommons.org/licenses/by-sa/4.0/legalcode>). Uvedené se nevztahuje na díla či prvky (např. obrazovou či fotografickou dokumentaci), které jsou v díle užity na základě smluvní licence nebo výjimky či omezení príslušných práv. 